\title{
Trade Promotion as a Means of Achieving Nigeria's Vision 20:2020
}

\author{
Badmus Adejare $\mathrm{S}^{1}$. Olabode Bashir O. ${ }^{2}$ \\ ${ }^{I}$ (General Studies Department, The Polytechnic, Ibadan, Oyo State, Nigeria) \\ ${ }_{2}^{2}$ (General Studies Department, The Polytechnic, Ibadan, Oyo State, Nigeria)
}

\begin{abstract}
Nigerian economy had undergone series of developmental programmes right from independence till date. One of the recent programmes is the Vision 20:2020 which has been designed to catapult the Nigerian economy into one of the twenty best economies in the world come year 2020. As laudable as this programme's objectives are, this paper examines how the main objective of the programme could be achieved through the promotion of trade.

In order to achieve this, this study has adopted the export-led- hypothesis, using the classical aggregate function. Regression analysis was used to determine whether the variation in economic growth represented with GDP in the past years was explained by a change in the volume of trade and the extent while the Augmented Dickey Fuller test was used to test the stationarity of the time series. The direction of causality of the variables was tested through the Granger causality test. The result revealed a significant positive relationship with economic growth while the Granger causality test revealed a unidirectional causal relationship from exports to GDP. This study confirms other similar ones carried out by other researchers on the relationship between trades and economic growth. Given this result, it was recommended that trade friendly policies should be formulated and strictly implemented for the achievement of Vision 20:2020.
\end{abstract}

Keywords: Economic Development Export, GDP, Import, Trade.

\section{Introduction}

At independence, many African countries including Nigeria were committed to achieving economic and social progress and development panning was the main strategies used by many governments to set their visions, missions, goals, and effective means of realizing economic and social progress (Olokesusi, 2011). Development planning has being a consistent phenomenon in Nigerian administrations since 1946. The Nigerian government has aspired to achieve development through the use of various types of plans, namely short term (annual budget), medium and long term plans. The Nigerian Vision 20:2020 is the latest in the history of medium term plans for the country and promises to surmount some of the problems that marred the success of previous plans.( Marcellus, 2009).

The Nigeria's Vision 20:2020 is an outcome of a research by the American Investment Bank which predicted that Nigeria will be in the league of 20 top economies given her abundant natural and human resources if these are efficiently managed. ( Abdulhamid, 2008 in Olokesusi, 2011).Vision 20:2020 is an articulation of the long term intent to launch Nigeria into a path of sustained social and economic progress and accelerate the emergence of a truly prosperous and united Nigeria. Recognizing the enormous human and natural endowments of the nation, the blue-print is an expression of Nigeria's intent to improve the living Standards of her citizens and place the country among the top 20 economies in the world with a minimum GDP of $\$ 900$ billion and a per capita income of not less than $\$ 4000$ per annum. The Vision's aspirations are defined across four dimensions:

(i) Social Dimensions: a peaceful, equitable, harmonious and just society, where every citizen has a strong sense of national identity and citizens are supported by an educational and healthcare system that caters for all, and sustains a life expectancy of not less than 70 years;

(ii) Economic Dimension: A globally competitive economy that is resilient and diversified with a globally competitive manufacturing sector that is tightly integrated and contributes not less than 25 percent to the Gross Domestic Product (GDP);

(iii) Institutional Dimension:A stable and functional democracy where the rights of the citizens to determine their leaders are guaranteed and adequate infrastructure exists to support a market-friendly and globally competitive business environment and

(iv) Environmental Dimension: A level of environmental consciousness that enables and supports sustainable management of the nation's God-given natural endowment to ensure their preservation for the benefit of present and future generations (NPC, 2009).

Based on these stated objectives of the developmental plan, this study seeks to evaluate the economic dimension via the possible contributions of the export sector towards the achievement of this objective. 


\subsection{Statement Of The Problem}

Trade accounts for the bulk of foreign exchange that the country earns before and after independence. The degree of openness was never below 50 percent from 1990 till date. For instance, it was 57 percent in 1990, 88 percent in 1995 and 58 percent in 2007. (Badmus A.S, 2010). The oil export accounted for over 80 percent of the total export during the oil boom era which simply means that it was the largest earner of foreign exchange to the country. Put differently, we can easily deduce that if export contributed to growth, then, oil export is a major contributor to this growth. But prior to this time, non-oil exports, specifically agricultural export contributed greatly to the total export and this was when Nigeria was an agrarian economy (in the 1960s) but with the advent of the discovery commercial quantities of crude oil in the early 1970s, especially during the oil boom of 1973-1974, the non-oil sector was neglected

Several efforts have been made by the Nigerian government to resuscitate the non-oil sector especially the agricultural sector in order to reduce the dependence of the economy solely on oil exports. This made the government to introduce several policies, strategies and programme to enhance output in the oil sector. For instance, in the mid 1960s and late 1970s, the government introduced Imports Substitution Industrialization Strategy (ISIS) in order to reduce volume of the hitherto imported products. According to Bankole et al (1999), the adoption of ISIS was not born out of the concern over sustainability of import bills but also out the desire for Nigeria to become an exporter, if not net, of industrial goods in the long term. After this, Export Promotion Strategy (EPS) was also embarked upon in order to encourage domestic output for export especially the non-oil exports. By late 1980s, Structural Adjustment Programme (SAP) was put in place to diversify Nigerian economy from the oil sector to the non-oil sector especially the agricultural and manufacturing sub-sector.

Nigeria also signed several bilateral, regional and trade preferential agreements with different countries in a bid to expand her market access. Apart from signing bilateral agreement with countries like; Jamaica, Romania, Bulgaria, Uganda, the government has also signed investment promotion and protection treaties with France, North-Korea, China, Turkey, Switzerland and Netherlands. Nigeria is also one of the founding members of the Economic Communities of West African States (ECOWAS) and of the World Trade Organization (WTO) and a signatory of Lome convention (Ogunkola and Oyejide, 2001). The Obasanjo's administration introduced new developmental strategy known as the National Economic Empowerment and Development Strategy (NEEDS) which would be used to propel economic development especially in the non-oil sector. The Seven Point Agenda of the Yar'adua's administration in 2007 also aimed at complementing government efforts at increasing production in the non-oil sector of the economy. The Vision 20:2020 is also another developmental plan aimed at leap-froging the economy to be among the 20 best economy in the year 2020 through inter alia the diversification of the economy so as not to depend solely on the oil sector for foreign exchange by developing the non-oil sector like; manufacturing, agricultural and other non-oil sectors.

Given these policies of the government, the intention was to develop the non-oil export sector so that more foreign exchange would be earned from this sector. Therefore, this study seeks to investigate the extent to which the export sector most especially the non-oil sector could contribute to achievement of Nigerian Vision 20:2020.

\subsection{Research Question}

This study seeks to provide answers to the following questions:

i. $\quad$ to what extent could trade contribute to the achievement of Vision 20:2020 in Nigeria.

ii which of the export sub-sector would contributes mostly to Vision 20:2020 in Nigeria.

iii Is there any need for policy adjustments towards the achievement of Vision 20:2020.

\subsection{Estimation Techniques}

We used the classical growth model as our methodology and the export-led growth hypothesis as the framework as adopted by Ekpo and Egwaikhide (1994) and Kareem (2009). This paper expands on the growth equation by including other potentially relevant variables such as; Oil Export (NOX), Non-oil Export (NNOX), Terms of Trade (TOT), Human Capital (HC), Total Government Expenditure TGEXPD) and Gross Fixed Capital Formation (GFCF).

\subsection{Sources Of Data}

The data to be used in this study are secondary data from CBN statistical Bulletin, CBN Annual Reports and Statement of Accounts and World Development Index (WDI) spanning through 1980-2007.

\section{Literature Review}

The literature is filled with various studies on the significance of trade on economic development. Generally, the studies have centered on the verification of Robertson's (1938) proposition that export is an engine of growth. This study therefore seeks to document the findings of scholars on this important subject. For instance Lawanson et al (2004) used the popular OLS techniques to investigate the impact of manufactured 
goods' export on economic growth in Nigeria and a close relationship was observed among the growth rates of real output, aggregate and manufactured exports investment and institutional coefficients. The result revealed that manufactured export have positive and statistically significant coefficients. It was later concluded that economic growth in Nigeria could be enhanced through trade policy hat supports export expansion, with increased emphasis on manufactured exports since the country stands to gain from this policy stance. In the same vein, Fajana's (1979) investigation on the correlation between exports and Nigeria's economic growth between 1964 and 1975 revealed a strong positive relationship.

Further evidence was given by Akerele (2001) on the role of exports and economic growth. Sources of instability in exports earnings for Nigerian economy for the period of 1980-1997 and observed that political as well as economic factors provided sources of instability in Nigeria's export earnings. The influence of political factors is not surprising since the period of the study coincided with the imposition of various sanctions on Nigeria for failure to adopt western-style democracy.

Similarly, Ekpo and Egwaikhide (1994) using the classical growth model and by including other variable like export into the model observe that there is a direct correspondence between growth in current exports and economic growth in Nigeria.

Ogbokor (2001) investigated the macroeconomic impact of oil export is undeniably a critical source of growth for the Nigerian economy. He also found out that a 10 percent increase in oil export would lead to a 5.5 percent jump in economic growth. He concluded that export oriented strategies should be given a more practical support by the relevant authority.

Ram (1976) in his study of India using time series data running from 1950 to 1971 investigated the export-led growth hypothesis. Relying on double log transformation regression equations, he noted that a percentage increase in export earnings is associated with 0.73 percent jump in domestic product.

Howard (2002) confirms that the economic growth in Trinidad and Tobago is granger-caused by the growth of exports. In his words, " a boom in exports of petroleum causes increased income and spending in the non-tradeable sector of the economy".

Hallicioglu (2007) opines that there is evidence that GDP causes export growth, an evidence of bidirectional causality between export and economic growth in Botswana. Ogbokor (2005) concludes that the export sector of the Zimbabwean economy experienced a dramatic downturn over the studied period as result of which economic and political isolation adversely affected the economy.

Lewis (1966) explains that, I additions to the multiple functions which export perform in the process of economic growth. It is also much easier for a country to begin its process of economic development via exporting. He cautioned, however, that this foreign market is usually very small in the early stage of development. He maintained that, the unique role of exports as a development strategy combine to make export an "engine of growth". This is why historically, the genesis of economic development in virtually every country have been induced by an increase in exports.

Also, the literature asserts that firms, which engage in exports, are more productive than firms that do not. For instance, Aw et al (1998) and Sjoholm (1999) confirm that there is a positive correlation between exports and productivity growth, in which case, firms that participate in the export market are "superior" extra productive, large, more lasting and pay higher wages than firms that do not. The two main sources of performance advantage of exporting firms over non-exporting firms are self-selection and learning by-exporting. In the case of the former, only the most productive firms are able to survive in the highly competitive export market. The latter is premised o the acquisition of some elements of productivity improvements that arise from knowledge and expertise, which the firm gains as a direct result of its export market experience. Collier and Gunning (1997) emphasized the existence of aggregate level evidence of lack of openness as the single most important cause of slow growth.

Table 1: The Performance Of Nigerian Export Sector

\begin{tabular}{|c|c|c|c|c|c|c|}
\hline Years & $\begin{array}{l}\text { Oil Exports as a } \\
\text { percentage of } \\
\text { total export }\end{array}$ & $\begin{array}{l}\text { Non-Oil Export } \\
\text { as a percentage } \\
\text { of total export }\end{array}$ & $\begin{array}{ll}\text { Percentage } & \text { of } \\
\text { Export } & \text { to } \\
\text { GDP } & \end{array}$ & $\begin{array}{l}\text { Percentage of } \\
\text { Oil Export to } \\
\text { GDP }\end{array}$ & $\begin{array}{l}\text { Percentage of } \\
\text { Non-Oil Export } \\
\text { to GDP }\end{array}$ & $\begin{array}{l}\text { Degree of } \\
\text { Openness }(\%)\end{array}$ \\
\hline 1980 & 96.1 & 3.9 & 28.6 & 27.5 & 1.1 & 23 \\
\hline 1985 & 95.8 & 4.2 & 16.6 & 15.9 & 0.7 & 27 \\
\hline 1990 & 97.0 & 3.0 & 40.4 & 39.2 & 1.2 & 57 \\
\hline 1995 & 97.6 & 2.4 & 49.1 & 47.9 & 1.2 & 88 \\
\hline 2000 & 98.7 & 1.3 & 41.2 & 40.7 & 0.5 & 62 \\
\hline 2005 & 97.5 & 2.5 & 42.5 & 41.8 & 0.7 & 68 \\
\hline 2006 & 97.7 & 2.3 & 31.0 & 30.3 & 0.7 & 54 \\
\hline 2007 & 97.9 & 2.1 & 34.9 & 34.2 & 0.7 & 58 \\
\hline
\end{tabular}

Source: Computed from CBN statistical Bulletin (several issues) 
The above table shows that throughout the years under study, the export sector's contribution to Nigeria's GDP has being on the increase except in the year 2006 when there was a slight drop. However, it has started to rise again, for instance, its share of the GDP rose marginally to about 35 percent in 2007.

\section{Theoretical Framework} follows:

The theoretical model that incorporates exports into the classical growth function is expressed as $\mathrm{Y}=\mathrm{f}(\mathrm{K}, \mathrm{L}, \mathrm{X})$

Where $\mathrm{Y}$ is output, $\mathrm{K}$ is capital, $\mathrm{L}$ is labour and $\mathrm{X}$ is exports of goods and services. The expected signs in the model would be positive for all the three variables because they are all expected to have positive effect on overall output. The expectation of positive signs is premised on the fact that as more capital and labour are used, output is expected to rise. Similarly, the positive sign expected for the export is derived from the assumption that export sector yields externalities that result in higher output by the non-export sector.

\subsection{Model Specification And Estimation Techniques}

In this study, we specify a multiple regression model that shows the effects of trade (represented by oil and non oil exports) on economic growth (represented by GDP). This study draws from that of Ekpo and Egwaikhide (1994) and Kareem (2009) which tried to analyze the effects of exports on economic growth in Nigeria. Therefore, the study specifies the following multiple regression equation using annual data for the natural logarithm of the variables from 1980 to 2007.

$$
\begin{aligned}
& \text { InY }_{\mathrm{t}}=\beta_{\mathrm{o}}+\beta_{1} \mathrm{GFCF}_{\mathrm{t}}+\beta_{2} \mathrm{InHC}_{\mathrm{t}}+\beta_{3} \operatorname{InTGEXPD}_{\mathrm{t}}+\beta_{4} \operatorname{InTOT}_{\mathrm{t}}+\beta_{5} \operatorname{InNOX}_{\mathrm{t}}+\beta_{6} \operatorname{InNNOX}_{\mathrm{t}}+\mathrm{E}_{\mathrm{t}} \ldots \\
& \text { where } \mathrm{Y}_{\mathrm{t}}=\text { Nominal GDP } \\
& \text { GFCF=Gross Fixed Capital Formation } \\
& \text { HC }=\text { Human Capital } \\
& \text { TGEXPD }=\text { Total Government Expenditure } \\
& \text { TOT }=\text { Terms of Trade } \\
& \text { NOX }=\text { Nominal Oil Exports } \\
& \text { NNOX = Nominal Non-Oil Exports } \\
& \text { Et }=\text { Stochastic error term. }
\end{aligned}
$$

Theoretically, economists believe that positive relationship exists between Gross fixed capital formation, human capital development, total government expenditure, nominal oil exports, nominal non-oil exports and economic growth. For the terms of trade, this can either be positive or negative (in the case of favourable and unfavourable terms respectively).

In this study, we specify a multiple regression model that shows the effects of trade proxy by export diversification from oil exports to non-oil exports.

\subsection{Granger Causality Test}

The Granger causality test was used to test the direction of causality between oil and non-oil exports (trade) and Nigeria's economic growth represented with GDP. This test is preferred to the correlation method that is sometimes used in many literatures given the fact that correlation does not necessarily imply causation in any meaningful sense of the word. There are several correlations which are simply spurious or meaningless in econometric analysis.

The Granger causality equation is:

$$
\begin{aligned}
& \mathrm{Y}_{\mathrm{t}}=\alpha \mathrm{i}+\sum \alpha \mathrm{X}_{\mathrm{t}-1}+\sum \beta 1 \mathrm{Y}_{\mathrm{t}-\mathrm{j}}+\mathrm{U} 1_{\mathrm{t}} \\
& \mathrm{X}_{\mathrm{t}}=\mathrm{bi}+\sum \lambda \mathrm{X}_{\mathrm{t}-1}+\sum \delta \mathrm{Y}_{\mathrm{j}-1}+\mathrm{U} 2_{\mathrm{t}} .
\end{aligned}
$$

Where $\mathrm{Y}$ and $\mathrm{X}$ represent economic growth and trade respectively. It is assumed that the disturbances $\mathrm{U} 1 \mathrm{t}$ and the U2t are uncorrelated. The F-statistic is used for the joint test of the hypothesis that:

In equation $3, \alpha 1=\alpha 2=. . \alpha n=0$ while

In equation $4, \delta 1=\delta 2=\delta \mathrm{n}=0$

The null hypothesis for the approach is that trade does granger- cause economic growth in the first regression equation and that economic growth does not granger cause improvement in the volume of trade in the second regression. Thus, F-statistic is used to accept or reject the null hypothesis. The equation 2 postulates that the current economic growth (GDP) is related to the past values of GDP as well as trade while, equation 4 indicates a similar behaviour for economic growth (GDP). The following three outcomes are possible in any granger causality test: 
a. Unidirectional causality: this occurs when one of the null hypothesis is accepted and the other rejected which means that the causality runs from GDP growth to growth in trade or from trade to GDP but not vice versa.

b. Bi-directional causality: here, both null hypotheses are rejected and this indicates that the causality runs from trade to GDP as well as from GDP to trade. In this case, we say there a feed-back or bilateral causality.

c. Independence: if both null hypotheses are accepted it means there is independence between trade and GDP. This indicates that the set of GDP growth and trade growth coefficients are statistically significant in both regressions. (Gujarati et al, 2009).

\section{Empirical Evidence}

The Granger causality's result is presented in Table 3. A 2-lag specification which was obtained from EVIEWS was used to determine the causality and the direction of causality between GDP and the explanatory variables. The table shows that there is a unidirectional causality from non-oil exports to GDP but not from GDP to non-oil exports i.e non-oil export granger causes growth in GDP but not vice versa.

However, in the case of oil exports and GDP, the result shows that there is a bi-directional causality from oil export to GDP and from GDP to oil exports. The null hypotheses were rejected which shows that oil export granger causes GDP and GDP also granger causes oil exports.

TABLE 3: Granger Causality Test Result

\begin{tabular}{|l|l|l|l|l|l|}
\hline Null Hypothesis & Observation & F-Statistics & Probability & Decision & Causality \\
\hline $\begin{array}{l}\text { LnNNOX } \\
\text { doesnot granger cause } \\
\text { lnGDP }\end{array}$ & 26 & 2.4870 & 0.0155 & Reject & \\
$\begin{array}{l}\text { LnGDP does not granger } \\
\text { cause lnNNOX }\end{array}$ & 1.3877 & 0.2716 & Accept & Unidirection \\
\hline $\begin{array}{l}\text { lnNOX does not granger } \\
\text { cause lnGDP }\end{array}$ & 26 & 3.4669 & 0.0033 & Reject & \\
$\begin{array}{l}\text { InGDP does not granger - } \\
\text { cause lnNOX }\end{array}$ & 2.3750 & 0.0247 & $\begin{array}{l}\text { Bi-directional or } \\
\text { Feed-Back }\end{array}$ \\
\hline
\end{tabular}

Source: Computed by the Author.

The regression result reveals that trade produces a significant positive effect on the GDP. For instance, a 10 percent increase in the value of non-oil exports would cause a marginal increase in the value of the GDP while a 10 percent increase in oil exports will also increase the GDP by approximately 6.5 percent. This implies that efforts of the government towards policies on the promotion of solid minerals and diversification of the economy from total dependence on oil exports to non-oil exports as spelt out among the objectives of Vision 20:2020 is yielding positive results.

Table 4: Regression Result

\begin{tabular}{|l|l|l|l|l|}
\hline & Coefficient & Std error & t-statistics & Probability \\
\hline Constant & 2.1985 & 0.4248 & 5.1749 & 0.0013 \\
\hline $\operatorname{lnGEXPD~}$ & $-9.39 \mathrm{E}-07$ & $5.28 \mathrm{E}-07$ & -1.7786 & 0.1185 \\
\hline $\operatorname{lnGFCF}$ & -0.0241 & 0.0443 & -0.5431 & 0.6039 \\
\hline $\ln$ TOT & 0.0458 & 0.0386 & 1.1859 & 0.2743 \\
\hline $\operatorname{lnNNOX}$ & 0.2554 & 0.1323 & 1.9298 & 00549 \\
\hline $\operatorname{lnNOX}$ & 0.6561 & 0.1312 & 4.9994 & 0.0016 \\
\hline LnHC & 0.0277 & 0.0108 & 2.5723 & 0.0369 \\
\hline $\mathrm{R}^{2}$ & 0.897645 & & & \\
\hline Adjusted $\mathrm{R}^{2}$ & 0.885627 & & & \\
\hline F.Statistics & 494.2526 & & & \\
\hline D. Watson & 2.312454 & & & \\
\hline
\end{tabular}

Source: Computed by the Authour.

The coefficient of determination (R2) depicts the explanatory power of the regressors to the tune of approximately 90 percent which is very robust. It means that economic growth is explained by the explanatory variables. The adjusted R2 is also very impressive at 89 percent. The durbin Watson statistics also shows that there is no auto-correlation among the explanatory variables. The Akaike Information Criterion (AIC) and the Schwartz Information Criterion (SIC) depicts the optimum lag length, the smaller their values the better. The result shows that the variables specified in the model are within the acceptable region. The F-statistics shows the joint significance of the explanatory variables and the value is also very impressive. 


\section{Summary, Conclusion And Recommendation}

The objective of this study is to evaluate the impact of trade in oil and non-oil exports on the achievement of Nigeria's Vision 20:2020. A causality analysis of the relevant variables was undertaken in order to verify the relevance of export-led growth hypothesis in the Nigerian economy.

The granger causality test was used to determine the direction of causality of the variables and the result depicts that there is a bi-directional causal relationship between oil exports and GDP. This means that a change in oil exports would cause a change in GDP also, a change in GDP would propel a change in oil exports. Meanwhile, in the case of non-oil exports and GDP, the result shows a unidirectional causality from non-oil exports to GDP but not vice versa.

The regression result shows that there is a significant positive relationship between non-oil exports and economic growth measured by nominal GDP which means that a 100 percentage change in non-oil exports will induce about 25 percent increase in GDP. expectedly, a 100 percent change in oil exports will also cause about a 66 percent increase in GDP both are significant at 5 percent confidence interval and result is similar to that of Ekpo and Egwaikhide (1994) and Kareem I.O (2009).

\subsection{Recommendations Policy Implication}

The primary policy implication of this study centres on the need to support continuous development of Nigeria external sector and the diversification of the economy from total dependence on oil sector to other non-oil sector. The country is blessed with many untapped commercial quantities of non-oil natural resources. These resources if well developed and tapped could bring a lot of fortune to the country from the rest of the world thus assisting in the achievement of the Vision.

Similarly, the manufacturing sector should also be developed and enabling environment should be provided in terms of regular power supply, grants, tariff reduction on imported intermediate products among others. It is hoped that the recent privatization of the power sector will boost the generation, transmission and distribution of power supply in the country. In effect, the cost of production would reduce thus encouraging the manufacturers to produce both for local and international markets at competitive prices.

The Tourism sector is also a potential contributor to the achievement of Vision 20:2020. Nigeria because of its divergent culture is blessed with a number of tourist attractions such as; Osun Groove, Olumo Rock, Erin Osun Water Fall among others which if well developed may be great sources of revenue to the government. Many countries such as Gambia, Saudi Arabia, Kenya e.t.c earn lots of foreign exchange and revenue from this sector. The Agricultural sector which used to be a major source of revenue and a major contributor to economic growth before Nigeria's independence should be resuscitated if the Vision 20:2020 is not going to become a mirage after all.

\subsection{Limitations Of The Study}

This study is constrained by the data used in the analysis. For instance, data were not got for more recent years which could have made the findings more real. Amongst the used data also, some years were missing and the researcher had to use the average of two consecutive periods in order to cover the vacuum. Similarly, we could not get values for depreciation for each of the years studied because of the problems which we encountered in getting values for depreciation. However, despite these shortcomings, the result still gives a reliable reference and a basis for further studies.

\section{References}

[1] Olokesusi, Femi. (2001). "Planning and the Achievement of Nigeria Vision 2020:20" a paper submitted to the Presidential Committee of the Nigerian Institute of Town Planners on the state of Urban and Regional Planning in Nigeria

[2] Marcellus I.O (2009): "Development Planning in Nigeria: Reflections on the National Economic Empowerment and Development Strategy (NEEDS) 2003- 2007”. Journal of Social Science vol. 3( 20).

[3] Abdulhamid Y. (2008). Nigeria: Vision 2020:20 and NPC Daily Trust, August 5 (online) available a http://allafiica.com/stones/2008Q8Q5Q705.html

[4] National Planning Commission. (2009). “Nigeria’s Vision 20:2020” Report of the Vision 20:2020 National Technical Working Group on Employment.

[5] Badmus A.S (2010): The Impact of Non-Oil Exports on Economic Growth in a Globalizing Economy: The Case of Nigeria. Being an Unpublished M.Sc Thesis submitted to the Department of Economics, Faculty of Social Science, University of Lagos, Nigeria

[6] Bankole A.S, Lawanson A.O and Aminu A (1999): Imports Competition and Nigeria's Manufacturing Sector: Analyses of the employment effects of trade. African Journal of Economic Policy vol.6(1)

[7] Ogunkola E.O and T.A Oyejide (2001): Market Access for Nigeria's Exports in European Union: An Assessment of Impact of the Lome Convention and Uruguay Round. The Nigerian Journal of Economics and Social Studies.vol. 43 (1)

[8] Lawanson O.T, Lawanson A.O and Bankole A.S. (2004) "Impact of Manufactured Goods' Exports on Economic Growth: A Dynamic, Econometric Model for Nigeria” African Journal of Economic Policy Vol.11(2)

[9] Fajana O. (1979): Trade and Growth: The Nigerian Experience. World Development 7, 73-8

[10] Akerele A.O. (2001): Nigeria's Export Trade: Instability and Forecast. Journal of Development Alternatives and Area studies. Vol. 20 
[11] Ekpo A.H and Egwaikhide F.O. (1994): Exports and Economic Growth in Nigeria: A Reconsideration of the Evidence. Journal of Economic Management Vol.1 December.

[12] Ogbokor C.A (2001): Nigeria's Export Trade Instability and Forecast. Journal of Development Alternatives and Area Studies 20:60-67

[13] Ram, M. (1976): Trade - An Engine of Economic Growth; The Case of India during the Planning Period. The Indian Journal of Economics. Vol. 56

[14] Howard M. (2002): Causality between Exports, Imports and Income in Trinidad and Tobago. International Economic Journal Vol. $16(4)$

[15] Halicioglu Ferda (2007) "A Multivariate Causality Analysis of Export and Growth for Turkey" Economics and Econometrics Research Institute. Rsearch Paper Series No.5

[16] Ogbokor C.A (2005): "Time-Series Evidence for Export-Led-Growth Paradigm: A Case Study of Zimbabwe. Journal of Social Sciences. Vol.1(.2).

[17] Lewis W.A. (1996): Some Aspects of Developing Nations. New York Oxford.

[18] Aw B.,Y.S. Chung and M.J. Roberts (1998): Productivity and Turnover in the Export Market: Micro Evidence from Taiwan and South Korea. NBER Working Paper No.16558

[19] Sjoholm, F. (1999). Export Imports and Productivity Result from Indonesian Establishment Data. World Development. 27((4).

[20] Collier P. and J.W. Gunning (1997): Explaining African Economic Performance. Centre for the Study of African Economies. WPS/97 2.2

[21] Kareem O.I (2009): A Test for the Validity of Export-Led Growth Hypothesis in Nigeria: A Further Evidence. Central Bank of Nigeria Economic and Financial Review vol. 46(3)

[22] Egwaikhide, F.O. (1995). Trade Policy Reform in Nigeria: A Historical Outline in External Trade and Economic Development in Nigeria. Nigerian Economic Society, Ibadan.

[23] Gujarati D.N., Dawn C. Porter and Sangeetha Gunasekar (2009): Basic Econometrics. The McGraw-Hill Companies, Inc. 122, Avenue of the Americas, New York . 